\title{
AVASCULAR NECROSIS OF THE FEMORAL HEAD IN HIV-INFECTED PATIENTS: PRELIMINARY RESULTS FROM SURGICAL TREATMENT FOR CERAMIC-CERAMIC JOINT REPLACEMENT
}

Henrique Amorim Cabrita', Alexandre Leme de Godoy Santos ${ }^{2}$, Riccardo Gomes Gobbi ${ }^{3}$, Ana Lúcia Munhoz Lima ${ }^{4}$, Priscila Rosalba Oliveira ${ }^{5}$, Leandro Ejnisman ${ }^{6}$, Henrique Melo Campos Gurgel', David Uip ${ }^{7}$, Gilberto Luis Camanho ${ }^{8}$

\section{ABSTRACT}

Objectives: To evaluate the initial functional results and early complication rate of ceramic-ceramic total hip replacements among patients living with HIV who presented osteonecrosis of the femoral head. Method: Twelve HIV-positive patients with a diagnosis of osteonecrosis of the incongruent femoral head were evaluated using clinical and laboratory criteria and the WOMAC functional scale before and after treatment with joint replacement. Results: We observed that $83.3 \%$ of the subjects were taking protease inhibitors, $75 \%$ had dyslipidemia and $66.6 \%$ had lipodys- trophy syndrome. The improvement over the evolution of the WOMAC score was statistically significant at six and twelve months after the operation, in comparison with the preoperative score. We did not observe complications secondary to this procedure. Conclusion: Total hip arthroplasty with a ceramic-ceramic implant for treating avascular necrosis of the hip is an appropriate surgical option for this portion of the population. It provides a significant initial functional improvement and a low early complication rate.

Keywords - HIV; Femur Head Necrosis; Arthroplasty; Dyslipidemias

\section{INTRODUCTION}

It has been estimated that around 630,000 people are living with HIV or AIDS in Brazil and, according to the parameters of the World Health Organization, this country has one of the highest concentrations of the epidemic, with a prevalence of HIV infection of $0.61 \%$ among the population aged 15 to 49 years $^{(1)}$.

The treatments available do not provide a cure and present variable efficiency and adverse effects. Thus, prevention is the best method of avoiding HIV infection and AIDS, and their consequences.

Studies have indicated that the prevalence of osteo- articular alterations among patients living with HIV/ AIDS is high, and that the presence of the virus and highly active antiretroviral therapy are independent risk factors that are boosted by associated metabolic and immunological disorders ${ }^{(2,3)}$.

Osteonecrosis of the femoral head has an estimated annual incidence of $4 \%$ in this population, and mean bilaterality of $57 \%$. This is of concern because it affects a young group of patients, between their fourth and fifth decades of life, and presents evolution to collapse of the head and permanent partial incapacity in $80 \%$ of the cases that have had the disease for four years ${ }^{(3-7)}$.

1 - Attending Physician in the Hip Group, Institute of Orthopedics and Traumatology, HC/FMUSP, São Paulo, Brazil.

2 - Attending Physician in the Foot and Ankle Group and in the Trauma Group, Institute of Orthopedics and Traumatology, HC/FMUSP, São Paulo, Brazil.

3 - Attending Physician in the Knee Group, Institute of Orthopedics and Traumatology, HC/FMUSP, São Paulo, Brazil.

4 - Collaborating Professor and Head of the CCIH, Institute of Orthopedics and Traumatology, HC/FMUSP, São Paulo, Brazil.

5 - Infectologist in the Institute of Orthopedics and Traumatology, HC/FMUSP, São Paulo, Brazil.

6 - Trainee in the Hip Group, Institute of Orthopedics and Traumatology, HC/FMUSP, São Paulo, Brazil.

7 - Director of the Emílio Ribas Institute of Infectology, São Paulo, Brazil.

8 - Titular Professor of the Department of Orthopedics and Traumatology, School of Medicine, University of São Paulo, São Paulo, Brazil.

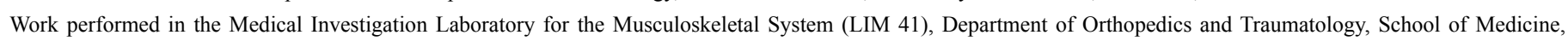
University of São Paulo.

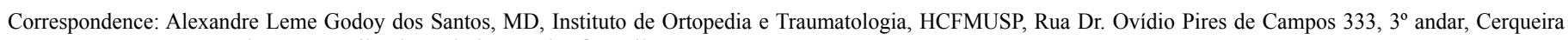
Cesar, 05403-010 São Paulo, SP. E-mail.: alexandrelemegodoy@gmail.com

Work received for publication: July 13, 2011; accepted for publication: December 21, 2011.

The authors declare that there was no conflict of interest in conducting this work 
The diagnosis is suspected based on the patient's history and appropriate physical examination, and early diagnosis is achieved by means of investigation using magnetic resonance imaging ${ }^{(3)}$.

The treatment options, which depend on the stage of evolution of the disease, include: motor physiotherapy to maintain joint movement and strengthen muscles; removal of weight-bearing from the affected limb; drug therapy using bisphosphonates; electrical therapy; bone decompression; and partial or total joint replacement ${ }^{(3-5)}$.

The present authors recently performed 12 total hip arthroplasty procedures secondary to osteonecrosis of the femoral head in patients living with HIV/AIDS. This article is based on our experience and focuses on the preoperative planning, care during the surgical procedure, postoperative complications and initial results from follow-up of more than 12 months.

\section{MATERIALS AND METHODS}

After obtaining approval from the Scientific Committee of the Institute of Orthopedics and Traumatology (IOT), University of São Paulo (USP), and from the Ethics Committee of Hospital das Clínicas, USP, under number 0606/08, 12 HIV-positive patients who were being followed up as cases of hip osteonecrosis were operated by the Osteo-HIV group of IOT-HCFMUSP between September and December 2009.

The inclusion criteria were the following: 1) positive serological test for HIV; 2) adherence to antiretroviral treatment at state care centers; 3) clinical release for the procedure after infectology assessment; 4) symptomatic hip osteonecrosis confirmed by means of magnetic resonance imaging; and 5) loss of sphericity of the femoral head.

All the patients underwent assessment of the clinical and laboratory criteria and measurement of the WOMAC score ${ }^{(8)}$.

All the patients were operated in lateral decubitus under regional anesthesia (spinal anesthesia). The route used was the Hardinge lateral approach ${ }^{(9)}$, by means of dissection of the tendons of the gluteus medius and vastus lateralis muscles. The joint capsule was preserved in all the procedures. The mean duration of the procedures was 122 minutes (range: 80 to 155 minutes).

The implants used were uncemented total prostheses, with a Summit nail, Pinnacle acetabulum and joint surfaces (in the acetabulum and femoral head) made of ceramic, zirconium and alumina (Johnson \& Johnson ${ }^{\circledR}$ ).

There were no intraoperative difficulties. Dissection of the soft tissues was facilitated by the small thickness of the adipose layer, a frequent characteristic of this population, which enabled adequate joint exposure through a small surgical incision. Manipulation of the bone tissue did not present indications of fragility with regard to cutting, milling and implant fixation (Figures 1, 2 and 3).

The acetabular component and the femoral nail were implanted under pressure (press fit), and complementary screws were used in the acetabulum in order to allow immediate loading (Figures 4 and 5).

Bone tissue from the femoral head, acetabulum and joint capsule were sent for anatomopathological examination and culturing to test for aerobic and anaerobic bacteria, fungi and mycobacteria.

A double-lumen Porto-Vac ${ }^{\circledR}$ drain of size 3.2 was used in all the patients and was removed on the second postoperative day. Standardized antimicrobial prophylaxis was used, consisting of $1.5 \mathrm{~g}$ of intravenous cefuroxime (Zinacef ${ }^{\circledR}$ ) every 12 hours for 24 hours.

The patients were kept with an abduction pad on the lower limbs until the first day after the operation. Physiotherapy was started immediately after the operation, while avoiding active adduction of the hip for three weeks.

The mean length of hospital stay was four days, and there was no need for support in an intensive care unit.

The patients were released for progressive partial

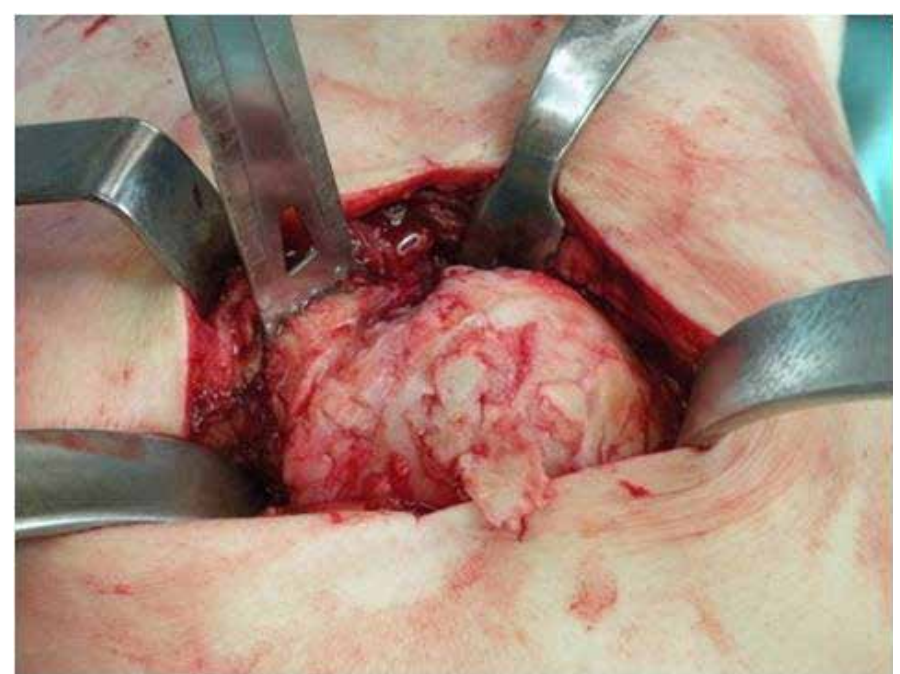

Figure 1 - Joint exposure of the left hip showing high degree of compromising of the femoral head. 


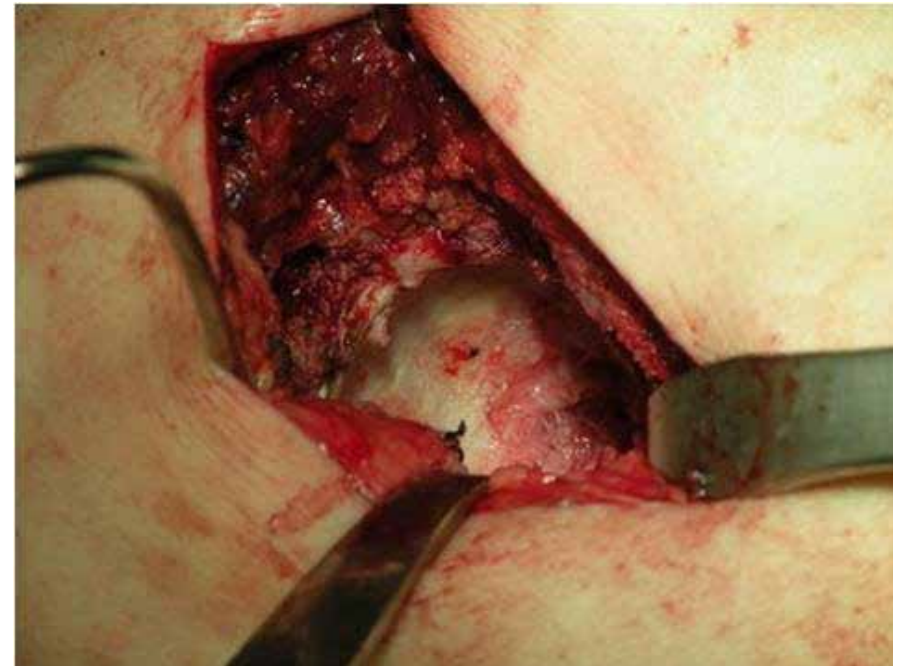

Figure 2 - Acetabular surface after milling.

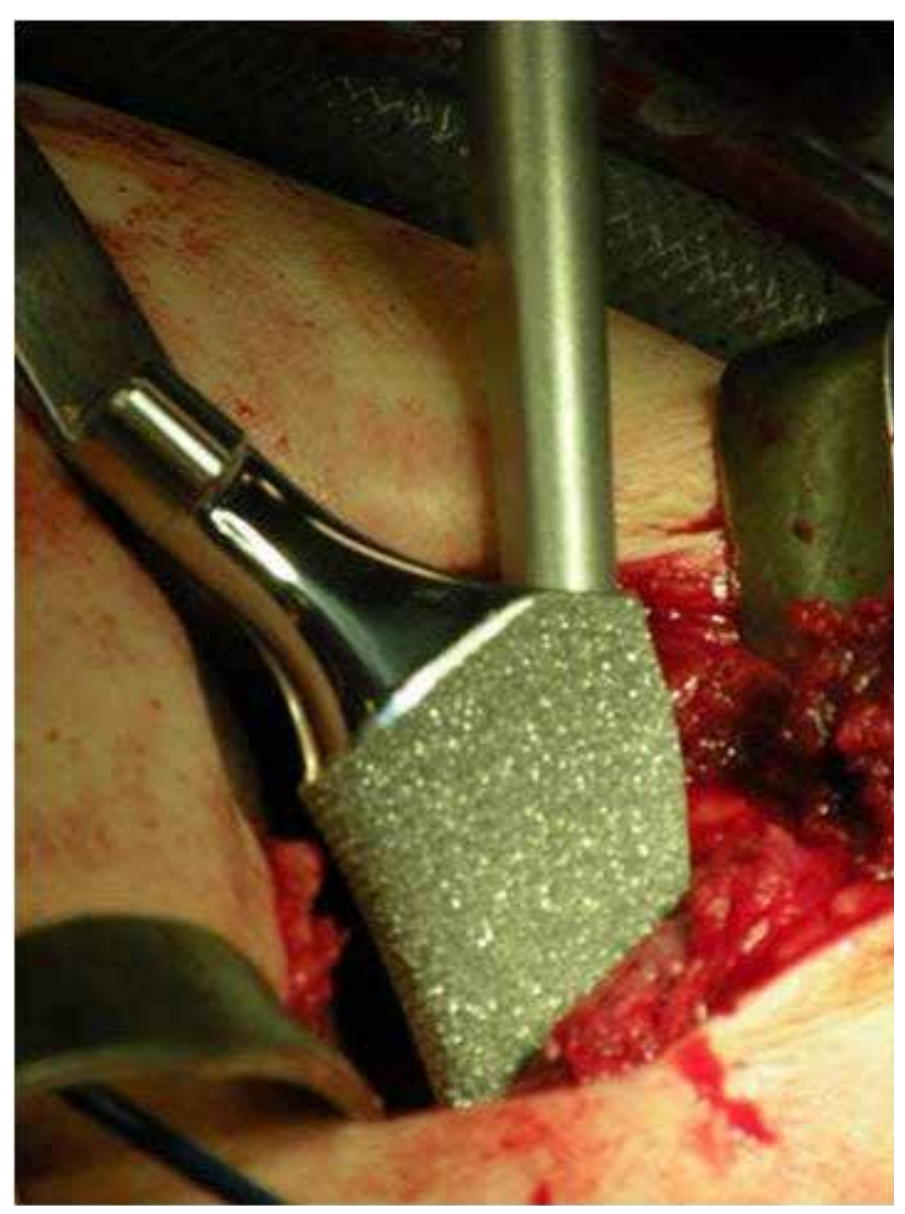

Figure 3 - Placement of the femoral nail under pressure (press fit).

loading on the first day after the arthroplasty, and full loading was reached in three weeks.

Low molecular weight heparin $\left(\right.$ Clexane $\left.^{\circledR}\right)$ at a dose of $40 \mathrm{mg} /$ day was used for 21 days in order to prevent thromboembolic events.

The stitches were removed at the first outpatient return visit, 10 days after the operation. Outpatient

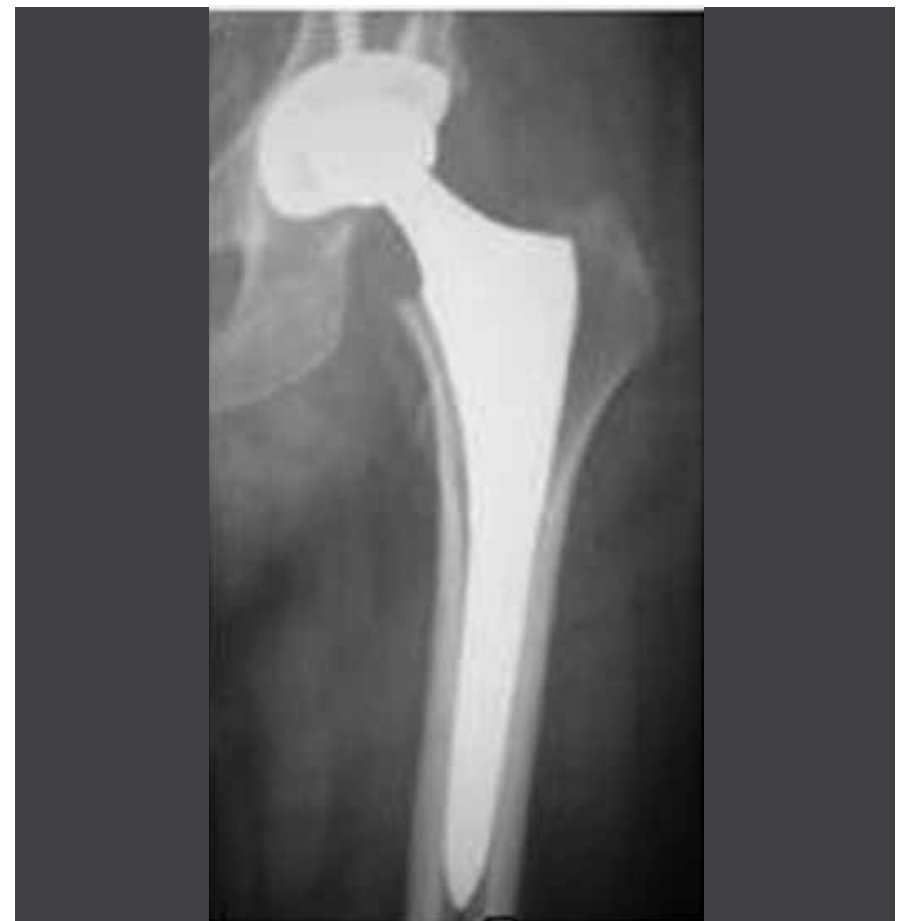

Figure 4 - Anteroposterior radiograph of the left hip showing fixation of the femoral and acetabular components.

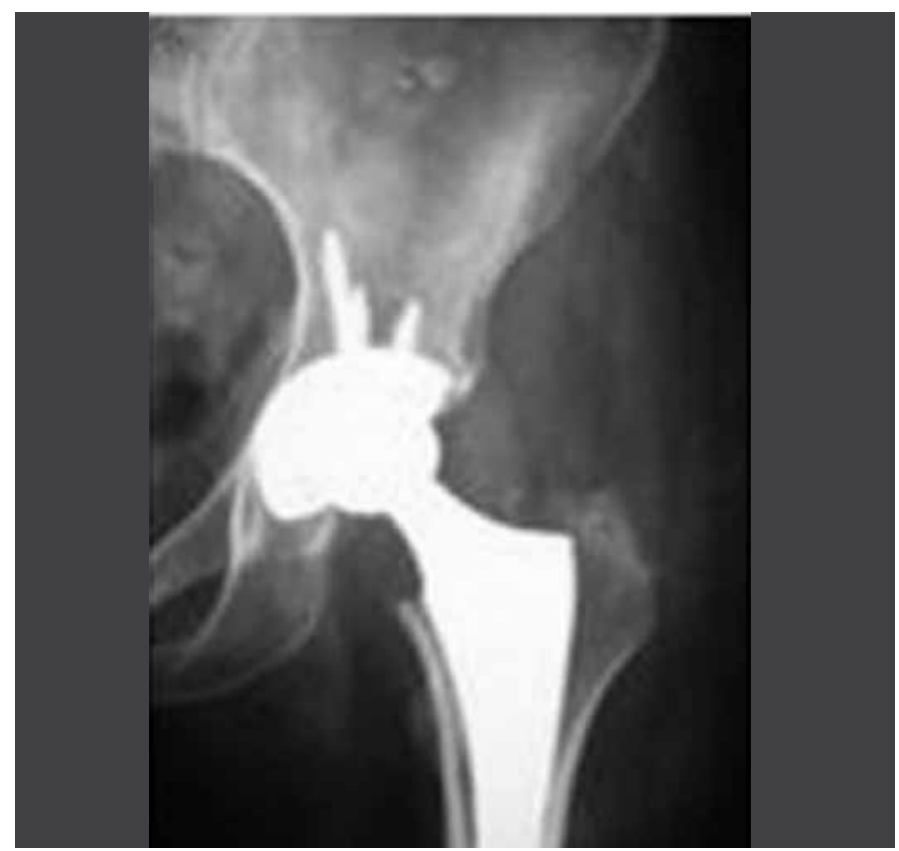

Figure 5 - Expanded anteroposterior radiographic view of the left hip showing good metaphyseal fixation of the femoral nail and distribution of the fixation screws of the acetabular component.

follow-ups were done 10 days, one month, three months and six months after the surgery.

Table 1 describes the laboratory data, disease history and use of antiretroviral medication among the sample.

Chart 1 describes the demographic characteristics, means of the laboratory findings, disease history and use of antiretroviral medication. 
Table 1 - Distribution of the laboratory parameters, periods of disease duration and use of antiretroviral medication among the sample.

\begin{tabular}{c|c|c|c|c}
\hline (months) & $\begin{array}{c}\text { CD4 (cell/ } \\
\mathbf{m m}^{3} \text { ) }\end{array}$ & $\begin{array}{c}\text { Disease } \\
\text { duration } \\
\text { (months) }\end{array}$ & $\begin{array}{c}\text { Viral load } \\
\text { (copies/ } \\
\text { mL) }\end{array}$ & $\begin{array}{c}\text { Duration of } \\
\text { medication } \\
\text { use }\end{array}$ \\
\hline Patient 1 & 415 & 120 & $<50$ & 120 \\
\hline Patient 2 & 373 & 84 & $<50$ & 82 \\
\hline Patient 3 & 563 & 164 & Undetectable & 121 \\
\hline Patient 4 & 290 & 180 & Undetectable & 132 \\
\hline Patient 5 & 892 & 168 & 60 & 168 \\
\hline Patient 6 & 614 & 132 & Undetectable & 132 \\
\hline Patient 7 & 371 & 228 & Undetectable & 192 \\
\hline Patient 8 & 586 & 72 & 71 & 72 \\
\hline Patient 9 & 147 & 132 & Undetectable & 96 \\
\hline Patient 10 & 428 & 72 & Undetectable & 72 \\
\hline Patient 11 & 221 & 120 & Undetectable & 48 \\
\hline Patient 12 & 445 & 96 & Undetectable & 96 \\
\hline
\end{tabular}

Chart 1 - Demographic, laboratory and clinical data of the sample.

\begin{tabular}{|c|c|}
\hline Mean age & 45 years (range: 32 to 65$)$ \\
\hline Gender & Male $(n=11) /$ female $(n=1)$ \\
\hline Side affected & Bilateral $(n=6) /$ unilateral $(n=6)$ \\
\hline Mean CD4 lymphocyte count & 454 cells/ml $(147$ to 892$)$ \\
\hline Viral load & Undetectable $(n=9)$ \\
\hline Mean length of time with HIV & 131 months $(72$ to 228$)$ \\
\hline $\begin{array}{c}\text { Mean length of time using } \\
\text { antiretroviral therapy }\end{array}$ & 131 months $(72$ to 192$)$ \\
\hline
\end{tabular}

${ }^{*}$ TARV = terapia antirretroviral

\section{RESULTS}

The patients' mean WOMAC scores before the operation and six and twelve months after the operation were respectively $64.2,19.3$ and 10.3 , as shown in Chart 2.

\section{DISCUSSION}

Avascular necrosis of the femoral head is a disease secondary to compromising of the vascular system of the proximal region of the femur. Although many patients do not present any specific identified etiological factor, the risk factors and conditions have been well determined in the literature ${ }^{(10)}$.

The incidence of osteonecrosis of the femoral head in the general population ranges from 0.010 to $0.135 \%$, while in the HIV-positive population it ranges from 1.33 to $4.4 \%{ }^{(3,11,12)}$.

The Osteo-HIV service of the Institute of Orthope-
Chart 2 - WOMAC score before the operation and after six and twelve months of follow-up, and presence of dyslipidemia and lipodystrophy.

\begin{tabular}{|c|c|c|c|}
\hline Patient & $\begin{array}{c}\text { WOMAC score before } \\
\text { operation and after } \\
\text { six and 12 months of } \\
\text { follow-up } \\
\text { (before/six/twelve) }\end{array}$ & Dyslipidemia & Lipodystrophy \\
\hline 1 & $71 / 21 / 3$ & + & + \\
\hline 2 & $89 / 19 / 19$ & - & + \\
\hline 3 & $66 / 19 / 13$ & + & + \\
\hline 4 & $45 / 7 / 7$ & - & - \\
\hline 5 & $73 / 32 / 15$ & + & - \\
\hline 6 & $64 / 26 / 16$ & + & + \\
\hline 7 & $48 / 24 / 1$ & + & + \\
\hline 8 & $46 / 15 / 1$ & + & + \\
\hline 9 & $64 / 17 / 13$ & + & + \\
\hline 10 & $80 / 34 / 26$ & + & - \\
\hline 11 & $57 / 4 / 4$ & + & - \\
\hline 12 & $68 / 14 / 6$ & - & + \\
\hline
\end{tabular}

dics and Traumatology of USP had 983 patients under follow-up; $11 \%$ of this group presented complaints relating to the coxofemoral joint, and 65 patients were treated for avascular necrosis of the femoral head.

Among patients living with HIV, viral infection and antiretroviral therapy are independent risk factors. The presence of hypertriglyceridemia, anticardiolipin antibodies and lipodystrophic syndrome and use of protease inhibitors increase the risk of developing osteonecrosis $^{(3-5)}$.

In the sample presented, we found that $83.3 \%$ were using protease inhibitors, $75 \%$ had dyslipidemia and $66.6 \%$ had lipodystrophic syndrome, and these findings were concordant with data in the literature.

The surgical technique used was the Hardinge approach. Despite the high prevalence of osteopenia and osteoporosis in this population of patients, we did not observe any technical difficulty in implanting the prosthetic components, and the osseointegration observed in the outpatient control radiographs presented normal patterns ${ }^{(13-16)}$.

The patients' young age group, high demand on the joints and risk of harm to renal function due to release of metal particles explain why joint surfaces made of ceramic and uncemented acetabular and femoral components made of porous metal are chosen. These characteristics provide high durability for the implants, with preservation of the bone stock, longer intervals until surgical revision is needed, low production of joint metalosis, low incidence of aseptic 
loosening and low systemic and local risks ${ }^{(12,17,18)}$.

The decreases in WOMAC score among these patients, six and twelve months after the operation, demonstrate that there were significant improvements regarding pain, locomotor function and quality of life. Moreover, these indicate postoperative evolution that is as fast as or faster than that of the general population, possibly due to the young age group of the sample of the present study ${ }^{(19-21)}$.

We did not observe any postoperative complications, although data in the literature indicate infection rates after this procedure in patients living with HIV ranging from 14 to $1.85 \%{ }^{(6,22,23)}$.

\section{CONCLUSION}

Total hip arthroplasty using a ceramic-ceramic implant to treat avascular necrosis of the hip in HIV-positive patients with a collapsed femoral head was shown to be an adequate surgical option, presenting significant initial functional improvement and a low early complication rate.

\section{REFERENCES}

1. Boletim Epidemiologico 2010 MS/SVS/Departamento de DST, Aids e Hepatites Virais. [acesso em 30 junho de 2009]. Disponível em: www.datasus.gov.br

2. Warriner $\mathrm{AH}$, Mugavero $\mathrm{MJ}$. Bone changes and fracture risk in individuals infected with HIV. Curr Rheumatol Rep. 2010;12(3):163-9.

3. Allison GT, Bostrom MP, Glesby MJ. Osteonecrosis in HIV disease: epidemiology, etiologies, and clinical management. AIDS. 2003;17(1):1-9.

4. Miller KD, Masur H, Jones EC, Joe GO, Rick ME, Kelly GG, et al. High prevalence of osteonecrosis of the femoral head in HIV-infected adults. Ann Intern Med. 2002;137(1):17-25

5. Morse CG, Mican JM, Jones EC, Joe GO, Rick ME, Formentini E, Kovacs JA. The incidence and natural history of osteonecrosis in HIV-infected adults. Clin Infect Dis. 2007;44(5):739-48.

6. Mahoney C, Glesby M, Dicarlo E, Peterson M, Bostrom M. Total hip arthroplasty in patients with human immunodeficiency virus infection. Acta Orthop. 2005;76(2):198-203.

7. Chevalier X, Larget-Piet B, Hernigou $P$, Gherardi R. Avascular necrosis of the femoral head in HIV-Infected patients. J Bone Joint Surg Br. 1993;75(1):160.

8. Bellamy N, Buchanan WW, Goldsmith $\mathrm{CH}$, Campbell J, Stitt LW. Validation study of WOMAC: a health status instrument for measuring clinically important patient relevant outcomes to antirheumatic drug therapy in patients with osteoarthritis of the hip or knee. J Rheumatol. 1988;15(12):1833-40.

9. Hardinge K. The direct lateral approach to the hip. J Bone Joint Surg Br. 1982;64(1):17-9.

10. McGrory BJ, York SC, lorio R, Macaulay W, Pelker RR, Parsley BS, et al. Current practices of AAHKS members in the treatment of adult osteonecrosis of the femoral head. J Bone Joint Surg Am. 2007;89(6):1194-204.

11. Mankin HJ. Nontraumatic necrosis of bone (osteonecrosis). New Engl J Med. 1992;326(22):1473-9.

12. Yoo JJ, Chun SH, Kwon YS, Koo KH, Yoon KS, Kim HJ. Operations about hip in human immunodeficiency virus-positive patients. Clin Orthop Surg. 2010;(1)2:22-7.
13. Amorosa V, Tebas P. Bone disease and HIV infection. Clin Infect Dis. 2006;42(1):108-14

14. Bruera D, Luna N, David DO, Bergoglio LM, Zamudio J. Decreased bone mineral density in HIV-infected patients is independent of antiretroviral therapy. AIDS. 2003;17(3):1917-23.

15. Delaunay C, Loiseau-Peres S, Benhamou CL. Osteopenia and human immunodeficiency virus. Joint Bone Spine. 2002;69(2):105-8.

16. Dolan SE, Huang JS, Killilea KM, Sullivan MP, Aliabadi N, Grinspoon S. Reduced bone density in HIV-infected women. AIDS. 2004;18(3):475-83.

17. Kim YH, Choi Y, Kim JS. Cementless total hip arthroplasty with ceramic-onceramic bearing in patients younger than 45 years with femoral-head osteonecrosis. Int Orthop. 2009;34(8):1123-7.

18. Lieberman JR, Berry DJ, Mont MA, Aaron RK, Callaghan JJ, Rajadhyaksha $A D$, Urbaniak JR. Osteonecrosis of the hip: management in the 21st century. Instr Course Lect. 2003;52:337-55.

19. Anseth SD, Pulido PA, Adelson WS, Patil S, Sandwell JC, Colwell CW. FifteenYear to Twenty-Year Results of Cementless Harris-Galante Porous Femoral and Harris-Galante Porous I and II Acetabular Components. J Athroplasty. 2010;25(5):687-91.

20. Archibeck MJ, Berger RA, Jacobs JJ, Quigley LR, Gitelis S, Rosenberg AG, et al. Second-generation cementless total hip arthroplasty. Eight to eleven-year results. J Bone Joint Surg Am. 2001;83(11):1666-73.

21. Greene JW, Malkani AL, Kolisek FR, Jessup NM, Baker DL. Ceramic-on-ceramic total hip arthroplasty. J Arthroplasty. 2004;24(1):15-8.

22. Lehman CR, Ries MD, Paiement GD, Davidson AB. Infection after total joint arthroplasty in patients with human immunodeficiency virus or intravenous drug use. J Arthroplasty. 2001;16(3):330-5.

23. Horberg MA, Hurley LB, Klein DB, Follansbee SE, Quesenberry C, Flamm $\mathrm{JA}$, et al. Surgical outcomes in human immunodeficiency virus-infected patients in the era of highly active antiretroviral therapy. Arch Surg. 141(12);2006:1238-45 